\title{
EFFECT OF PROTECTED PROTEIN ON GROWTH PERFORMANCE OF CROSSBRED FRIESIAN CALVES FED CORN SILAGE-BASED DIETS \\ El-Shabrawy, H.M. ${ }^{1}$; M.M. EI-Deeb ${ }^{1}$; K.E. I. Etman ${ }^{1}$ and A.Z. Mehrez ${ }^{2}$ \\ 1. Animal Nutrition Department, Animal Production Research Institute, Agricultural Research Centre, Ministry of Agric., Dokki, Giza, Egypt. \\ 2. Animal Production Dept., Faculty of Agric., Mansoura University.
}

\section{ABSTRACT}

Eighteen crossbred Friesian calves weighed $95.3 \pm 1.74 \mathrm{Kg}$ on average were used in a feeding trial lasted for 180 days. Animals were divided into three similar groups (6 calves each) to study the effects of protecting proteins of soybean meal (SBM) and un-decorticated cottonseed meal (UCSM) by zinc sulphate on nutrients digestibility, some rumen fermentation characteristics, plasma metabolite concentrations and their reflection on growth performance of calves fed corn silage based diets. The ratio of corn silage to concentrate was 67 to 33 on the basis of dry matter and fed ad libitum. Diets were supplemented with SBM and UCSM; Zn-SBM and Zn-UCSM or a $50: 50$ combination of both Zn-protected and untreated sources.

The obtained results indicated that digestibility coefficients of DM, OM, CP, CF and NFE for calves fed treated proteins by zinc sulphate increased than those fed untreated materials. The improvements in digestibility of nutrients reflected better feeding values in terms of TDN and DCP for diets containing treated proteins than the control ones.

Ruminal $\mathrm{NH}_{3}-\mathrm{N}$ and NPN concentrations were lower $(\mathrm{P}<0.05)$ for calves fed treated proteins by zinc sulphate than those fed untreated diet, indicating efficiency of the protection and / or better synchronization between availability of energy and release of $\mathrm{NH}_{3}$. On the other hand, ruminal true protein nitrogen (TPN) and protozoa count were higher $(\mathrm{P}<0.05)$ for calves fed zinc sulphate treated proteins and those received a ratio of $50: 50$ of combined treated sources than those fed the untreated ones. Ruminal acetic acid concentration decreased by $11.15 \%$ for calves fed protected proteins than those fed untreated proteins, whereas ruminal propionic acid increased by $8.29 \%$.

The concentration of plasma urea- $N$ was decreased $(P<0.05)$ in calves fed treated proteins by zinc sulphate than untreated materials, indicating better utilization of protected proteins. Whereas, the zinc sulphate protected protein diet resulted in the highest $(P<0.05)$ values for plasma total protein, albumin and globulin concentrations.

Average daily gain $(A D G)$ was significantly $(P<0.05)$ higher for calves fed treated proteins followed by calves fed diet treated and untreated proteins with a 50 : 50 combination of both $\mathrm{Zn}$-protected and untreated ones, being 1.272, 1.178 and $0.962 \mathrm{Kg} / \mathrm{h} / \mathrm{d}$, respectively. Moreover, feed conversion efficiency (expressed as DM, TDN and DCP, $\mathrm{Kg} / \mathrm{Kg}$ gain) were better for calves fed protected proteins than those fed unprotected proteins. Feed cost decreased by 29.8 and $25.7 \%$ for calves fed protected proteins and diet contained a $50: 50$ combination of both $\mathrm{Zn}$-protected and untreated proteins, respectively than those fed unprotected protein. Accordingly, economical efficiency improved by 29.9 and $25.8 \%$ with diets contained protected proteins or a $50: 50$ combination of both $\mathrm{Zn}$-protected and untreated sources than with diet contained untreated proteins.

From the aforementioned results, this study recommends the use of zinc sulphate as a protection method for half or all SBM and UCSM protein sources from degradation in the rumen during formulating rations for crossbred Friesian calves when feeding corn silage as a basal diet. 
Keywords: Friesian calves, weight gain, protected protein, zinc sulphate, digestibility, rumen, blood, economic

\section{INTRODUCTION}

Soybean meal (SBM) and un-decorticated cotton seed meal (UCSM) are the most commonly materials used as protein supplement in animal diets. However, SBM and UCSM have relative low protein efficiency because of their extensive degradation in the rumen. Their use is becoming limited in diets of high producing ruminant animals. Soybean meal is a very expensive protein source when the price calculated based on crude protein content, but it becomes feasible when the price is considered per kilogram of ruminal undegradable protein (RUP), especially ruminally undegradable methionine, therefore the use of SBM in the diets of high yielding animals appears to be much more economic. Accordingly, improving ruminal escape characteristics of SBM and UCSM are of a major importance to animal performance. Various methods of treating proteins have been used to reduce their degradation in the rumen. Treatment with zinc sulphate appears to be an efficient method.

Zinc $(Z n)$ is generally added to diets to ensure that nutritional requirements of $\mathrm{Zn}$ are met. However, $\mathrm{Zn}$ sometimes is used to affect the nutritional properties of feed. For example, $\mathrm{Zn}$ has been shown to reduce ruminal degradability of feed protein.

Britton and Klopfenstein (1986) demonstrated that treating soybean meal (SBM) with $\mathrm{Zn}$ salts at 1.5 to $2.0 \%$ of feed DM reduced In vitro degradation of SBM-protein and improved efficiency of $\mathrm{N}$ utilization by calves fed diets supplemented with Zn-treated SBM compared with solventextracted SBM.

Cecava et al. (1993) reported that ruminal escape $\mathrm{N}$ content for $\mathrm{Zn}$ SBM, estimated by $12 \mathrm{~h}$ ruminal incubation, was $90 \%$ greater than for solvent extracted SBM. Also, Karr et al. (1991b) found that $70 \%$ of $\mathrm{N}$ in Zn-SBM escaped ruminal degradation in cannulated sheep. Other researchers observed similar improvements in calf growth (Karr et al., 1991c) or milk production (Zimmerman et al., 1992) when diets contained Zn-treated SBM (Zn-SBM) compared with solvent-extracted SBM. The mechanism by which $\mathrm{Zn}$ salts can precipitate soluble proteins in laboratory procedures (Haurowitz, 1950) and studies increased flow of feed AA in lambs (Karr et al., 1991b) and steers (Froetschel et al., 1990) fed diets containing Zn-treated SBM. Karr et al. (1991a) suggested that $\mathrm{Zn}$ salts may inactivate proteolytic enzymes of selected ruminal bacteria, thus reducing ruminal proteolyses of dietary protein.

Cecava et al. (1993) reported that feeding a combination of ruminally degradable and un-degradable SBM as supplemental protein in diets based on corn silage and high-moisture corn increased the supply of amino acids to the small intestine compared with feeding protein source alone.

Under Egyptian conditions, few studies have been made on the effect of protected proteins by zinc on growth performance of farm animals. So, the main objective of the present study was to investigate the effects of protecting protein of soybean meal (SBM) and un-decorticated cotton seed meal 
(UCSM) by zinc sulphate in diets of crossbred Friesian calves on nutrients digestibility, some rumen fermentation characteristics, plasma metabolite concentrations and their reflection on growth performance of calves fed corn silage based diets.

\section{MATERIALS AND METHODS}

The current investigation was carried out at El-Serw experimental station, Animal Production Research Institute, Agricultural Research Center, Ministry of Agriculture, Egypt.

Eighteen crossbred Friesian calves, weighed $95.3 \pm 1.74 \mathrm{Kg}$ live body weight on average, were assigned randomly into three similar groups (6 calves each) according to their live body weight and were assigned at random to the three experimental treatments. Animals of each group were housed in separate stalls and fed in groups. Fresh and clean drinking water was available all the time.

Three experimental diets were formulated (Table 1) using local resources of ingredient materials, i.e. whole corn silage (WCS), soybean meal (SBM) and un-decorticated cotton seed meal (UCSM). Both of SBM or UCSM were either untreated or Zn-treated in the experimental diets. The SBM or UCSM were treated by spraying Zn-sulphate at the rate of $1.5 \%$ of feed DM (Brittion and Klopfenstein, 1986). The diets were prepared once daily as a total mixed rations and offered to animals once daily. The animals were fed ad libitum and the feed residual were weighed daily. The experimental diets were formulated so that ad lib intake would at least cover the recommended allowances $(\mathrm{NRC}, 1989)$ and $\mathrm{Zn}$-Oxide was added to diets 1 and 2 to equalize $\mathrm{Zn}$ concentrations among diets. All animals were fed on the tested diets containing $33 \%$ concentrate: $67 \%$ corn silage ratio (Table 1 ). The experiment lasted six months and the animals were weighed monthly before morning feeding. The amounts of consumed feed were recorded. Feed conversion and economical efficiency were therefore calculated.

Table (1): Formulation of the experimental diets (\% of DM).

\begin{tabular}{|l|c|c|c|}
\hline \multirow{2}{*}{\multicolumn{1}{c|}{ Ingredients }} & \multicolumn{3}{c|}{ Experimental diets } \\
\cline { 2 - 4 } & Diet 1 & Diet 2 & Diet 3 \\
\hline Whole Corn silage, WCS & 67.0 & 67.0 & 67.0 \\
\hline Soybean meal, SBM & 10.0 & 5.0 & - \\
\hline Zinc-SBM & - & 5.0 & 10.0 \\
\hline Un-decorticated cotton seed meal, UCSM & 20.0 & 10.0 & - \\
\hline Zinc-UCSM & - & 10.0 & 20.0 \\
\hline Limestone & 1.25 & 1.25 & 1.25 \\
\hline Sodium chloride & 0.73 & 0.74 & 0.75 \\
\hline Dicalcium phosphate & 0.5 & 0.5 & 0.5 \\
\hline Minerals and vitamins mixture* & 0.5 & 0.5 & 0.5 \\
\hline Zinc oxide & 0.02 & 0.01 & - \\
\hline
\end{tabular}

* Each Kg contained P, 40 g; Ca, 50 g; Mg. 50 g; Mn, 4.5 g; S, 12 g; Fe, 7 g; Cu, 2 g; Se, 12 $\mathrm{mg}, \mathrm{Co}, 50 \mathrm{mg}$; vitamin A, $2000000 \mathrm{IU}$; vitamin D, $20000 \mathrm{IU}$ and vitamin E, $20 \mathrm{mg}$ (Biomix 33, produced by Biochema,, Cairo, Egypt). 
Digestibility trials were carried out at the end of the feeding experiment using three random animals from each group to determine the digestion coefficients and nutritive values of the tested rations used in the feeding trial. Fecal samples were gripped from the rectum of each animal twice daily during the collection period (5 days). Acid insoluble ash (AIA) was used as a natural marker (Van Keulen and Young, 1977).

Samples of WCS, SBM and UCSM were collected weekly throughout the experiment. Dry matter was assayed after the samples were ground through a $1 \mathrm{~mm}$ screen hammer mill and dried at $105^{\circ} \mathrm{C}$ for 3 hours except those of silages and feces were first dried at $60^{\circ} \mathrm{C}$ for 48 hours and analyzed for ash, crude fiber, crude protein, ether extract, zinc according to A.O.A.C (1990).

At the end of digestibility trial, rumen fluid samples were taken from three animals in each group just before offering morning meal and 4 hours post-feeding using stomach tube. Rumen-fluid $\mathrm{pH}$ was measured immediately on a fresh aliquot using battery operated $\mathrm{pH}$ meter and then samples were filtered through two layers of surgical gauze. Total volatile fatty acids (VFA's) concentrations were estimated using steam distillation method (Warner, 1964). Ammonia- $\mathrm{N}\left(\mathrm{NH}_{3}-\mathrm{N}\right)$ concentration was assayed according to Conway and O'Mally (1957). Molar proportions of VFA's were determined according to Erwin et al. (1961) and Protozoa count carried out according to Abou El-Naga (1967). Ruminal total nitrogen (TN) and non-protein nitrogen (NPN) were determined according to A.O.A.C (1990). True protein nitrogen (True-PN) was estimated by the difference between TN and NPN.

At the end of the digestibility trial, blood samples were collected in heparinized test tubes from the jugular vein from three animals of each group before morning feeding and 4 hours post-feeding. Blood samples were centrifuged immediately at 3500 revolution per minute $(\mathrm{rpm})$ for 15 minutes to separate blood plasma and stored at $-20^{\circ} \mathrm{C}$ until further analysis. Blood plasma was analyzed for urea-N (Patton and Crouch, 1977), total protein (Peters, 1968), and albumin (Webster, 1974). Globulin concentration was calculated by difference (Total protein-albumin). Calcium and zinc were determined in blood plasma using kits of SENTINEL, CH., Milano, Italy by means of spectrophotometer at the Sheep and Goats Departments' laboratory, Animal Production Research Institute. Inorganic phosphorus was determined in blood plasma sing kits of QCA., Amposta, Spain by means of spectrophotometer, in the same laboratory.

Data of growth performance and feed evaluation were subjected to statistical analysis by the computer program of SAS (1996) using the General Linear Model (GLM), according to the following model:

Where:

$$
Y i j=U+A i+e i j
$$

Yij = observed traits, $\mathrm{U}=$ overall mean, $\mathrm{A}=$ =experimental diets $1-3\left(1=\right.$ diet $_{1}, 2=$ $\operatorname{diet}_{2}$ and $3=\operatorname{diet}_{3}$ ), eij $=$ Random error. The data of rumen liquor and blood metabolites were subjected to two-way analysis of variance for examing of effect of treatments (diet 1 , diet 2 and diet $_{3}$ ) and time of sampling (0 and 4 hours)and their interaction according to the following model: 
$Y i j k=U+A i+T j+A T i j+e i j k$

where: Yiijk $=$ observed traits, $U=$ overall mean, $A i=$ experimental diets $1-3$ (1 $=\operatorname{diet}_{1}, 2=\operatorname{diet}_{2}$ and $\left.3=\operatorname{diet}_{3}\right), \mathrm{Tj}=$ time of sampling, ATij $=$ interaction, eijk $=$ Random error. Means were compared according to Duncan's Multiple Range Test at 0.05 level (Duncan, 1955). It was found that the interaction diet $X$ time was not significant, the main effects will be only presented in the results and discussion.

\section{RESULTS AND DISCUSSION}

\section{Experimental diets:}

Formulation of the experimental diets and the chemical composition of the ingredients used to formulate the total mixed rations are presented in Tables 1 and 2. The chemical composition of the ingredients was within the normal published ranges (Abou-Raya ,1967, MOA, 1997, El-Shabrawy, 2000 and El-Shabrawy and El-Fadaly, 2006); except for CP content which was relatively lower in SBM (37.48\%) due to its high content of EE (5.43\%). The calculated chemical composition of the tested diets seemed to be similar in their nutrient content. The determined $\mathrm{Zn}$ contents of the tasted diets were $380.0,341.0$ and $416.0 \mathrm{mg} / \mathrm{kg}$ diet for diet 1,2 and 3 respectively.

Table (2): Chemical composition of the tested ingredients and the experimental diets.

\begin{tabular}{|l|c|c|c|c|c|c|c|}
\hline \multirow{2}{*}{ Ingredients } & DM & \multicolumn{7}{|c|}{ Chemical composition on DM basis (\%) } \\
\cline { 3 - 8 } & $(\%)$ & OM & CP & EE & CF & NFE & Ash \\
\hline WCS & 30.59 & 91.99 & 8.30 & 3.25 & 26.30 & 54.14 & 8.01 \\
SBM & 89.92 & 93.20 & 37.48 & 5.43 & 5.21 & 44.68 & 6.80 \\
Zn-SBM & 88.40 & 93.30 & 37.55 & 5.30 & 5.50 & 44.95 & 6.70 \\
UCSM & 90.05 & 94.30 & 25.60 & 5.94 & 24.72 & 38.04 & 5.70 \\
Zn-UCSM & 88.60 & 94.18 & 25.75 & 5.80 & 24.50 & 38.13 & 5.82 \\
\hline \multicolumn{7}{|c|}{ Calculated chemical composition of the tested diets(\%) } \\
\hline Diet (1) & 47.49 & 89.81 & 14.43 & 3.91 & 23.08 & 48.39 & 10.19 \\
Diet (2) & 47.28 & 89.80 & 14.44 & 3.88 & 23.07 & 48.41 & 10.20 \\
Diet (3) & 47.05 & 89.80 & 14.46 & 3.87 & 23.07 & 48.40 & 10.20 \\
\hline
\end{tabular}

Generally, the concentrations of $\mathrm{Zn}$ in the tested diets follows within the safe range for animal health according to Miller et al. (1965) and Kincaid et al. (1976).

\section{Digestibility coefficients and nutritive values:}

The results of digestibility coefficients and feeding values of the tested diets are presented in Table (3). It was clear that the lowest $(P<0.05)$ digestibility coefficients were recorded with diet (1) compared to those obtained with both diets (2 and 3). Meanwhile, diets (2) and (3) did not show significant differences among each other in digestibility coefficients of DM, $\mathrm{OM}, \mathrm{CF}$, while it shows significant $(\mathrm{P}<0.05)$ differences in $\mathrm{CP}, \mathrm{NFE}$. All the tested diets were not significantly different in EE digestion. On the other hand, positive improvements were recorded for TDN and DCP values with 
diet (3) compared to that of diets (2) and (1) in a decreasing rate, respectively with significant differences $(P<0.05)$ among them. The higher $D C P$ with the protected protein was probably because of higher crude protein digestibility.

Diet (3) was higher by about $7.97 \%$ and $2.63 \%$ for CP digestibility than diets (1) and (2), respectively. The improvement in CP digestibility might be related to $\mathrm{Zn}$ treatment as a protection method of protein, hence reducing protein solubility and degradability in the rumen and therefore provided more dietary protein for digestion and absorption in the small intestine which probably is better than the microbial protein (Cecava et al., 1993) if the quality of protected protein is higher.

The obtained results are on line with those reported by Karr et al. (1991b) and Cecava et al. (1993) who reported that ruminal escape N content for $\mathrm{Zn}-\mathrm{SBM}$ was $70 \%$ to $90 \%$ greater than for solvent-extracted SBM.

Moreover, regarding OM digestibility trend in the present study it seems that protection method improved its values with diet (3) compared with those recorded for diet (1) (being 73.57 Vs. 69.87\%). In this respect, Karr et al. (1991b) found significant effect on organic matter digestibility for sheep fed $\mathrm{Zn}-\mathrm{SBM}$ than those fed untreated-SBM. On the other hand, Cecava et al. (1993) reported that total tract OM digestibility was similar among treatments when they were fed $\mathrm{Zn}$-SBM compared with those given untreated SBM.

Table (3): Effect of the experimental diets on digestion coefficients and nutritive values.

\begin{tabular}{|c|c|c|c|c|}
\hline \multirow{2}{*}{ Item } & \multicolumn{3}{|c|}{ Experimental diets } & \multirow{2}{*}{ SEM } \\
\hline & Diet 1 & Diet 2 & Diet 3 & \\
\hline \multicolumn{5}{|c|}{ Digestibility coefficients (\%) } \\
\hline DM & $67.88^{b}$ & $71.19^{\mathrm{a}}$ & $71.74^{\mathrm{a}}$ & 0.48 \\
\hline OM & $69.87^{b}$ & $72.88^{a}$ & $73.57^{a}$ & 0.58 \\
\hline $\mathbf{C P}$ & $68.91^{\mathrm{C}}$ & $72.49^{\circ}$ & $74.40^{a}$ & 0.55 \\
\hline EE & 77.75 & 77.54 & 78.14 & 0.54 \\
\hline CF & $63.38^{b}$ & $68.58^{\mathrm{a}}$ & $70.75^{a}$ & 0.69 \\
\hline NFE & $68.33^{\mathrm{C}}$ & $71.06^{b}$ & $72.38^{a}$ & 0.25 \\
\hline \multicolumn{5}{|c|}{ Nutritive value (\%) } \\
\hline TDN & $64.48^{\mathrm{C}}$ & $67.46^{b}$ & $68.97^{a}$ & 0.23 \\
\hline DCP & $9.94^{\mathrm{C}}$ & $10.47^{b}$ & $10.76^{a}$ & 0.08 \\
\hline
\end{tabular}

Means within the same row having different superscripts are significantly different $(\mathrm{P}<0.05)$.

Certainly the influences on the digestibility of nutrients along the whole alimentary tract are mainly reflections of fermentation in the rumen in terms of availability of $\mathrm{N}$ for rumen microbes as a result of protein protection.

Haddad et al. (2005) and Soto-Navarro et al. (2006) reported that the digestibility coefficients of DM and CP for sheep increased when rumen undegradable protein (RUP) content of their diets increased.

\section{Some rumen fluid parameters:}

Data in Table (4) showed that $\mathrm{pH}$ values gave its maximum value with diet $(3)$ with significant $(P<0.05)$ difference compared with those recoded for diets (1) and (2). While, VFAs' concentrations took the reverse trend, since it recorded the lowest significant $(P<0.05)$ value with diet $(3)$ compared 
to those recorded with both diets 1 and 2 . These results are in agreement with those recorded by Pires et al. (1997) who reported higher ruminal pH values for dairy cows fed high RUP than those fed low RUP. For time effect, it is clear that the normal pattern showed in both pH and VFA concentration, since the first significantly $(P<0.05)$ decreased after feeding while VFA significantly $(\mathrm{P}<0.05)$ increased as recorded in several studies (El-Shabrawy, 2006) on lactating Zaraibi goats.

Regarding the molar proportions of individual volatile fatty acids, it was clear that acetic acid concentration significantly $(P<0.05)$ decreased from $50.63(\mathrm{~mol} / 100 \mathrm{~mol})$ in diet (2) to $44.32(\mathrm{~mol} / 100 \mathrm{~mol})$ in diet (3), while diet (1) gave intermediate value of 49.88 ( $\mathrm{mol} / 100 \mathrm{~mol})$, but without significant differences with the other two diets. Meanwhile, Propionic acid concentration recorded the highest value with diet (3) compared to those with diets (1 and 2) without significant differences among the tested diets.

Table (4): Mean effect of feeding the experimental diets on rumen liquor $\mathrm{pH}$ and volatile fatty acids of Friesian cross-bred calves.

\begin{tabular}{|l|c|c|c|c|c|c|c|}
\hline \multirow{2}{*}{ Items } & \multicolumn{3}{|c|}{ Experimental diets } & \multirow{2}{*}{ SEM } & Sampling time (hr) & \multirow{2}{*}{ SEM } \\
\cline { 2 - 7 } & Diet 1 & Diet 2 & Diet 3 & & $\mathbf{0}$ & $\mathbf{4}$ & \\
\hline pH & $6.37^{\mathrm{b}}$ & $6.50^{\mathrm{b}}$ & $6.79^{\mathrm{a}}$ & 0.09 & $6.78^{\mathrm{a}}$ & $6.33^{\mathrm{b}}$ & 0.08 \\
VFA (meq./100 mI RL) & $7.73^{\mathrm{a}}$ & $7.24^{\mathrm{a}}$ & $6.53^{\mathrm{b}}$ & 0.18 & $6.49^{\mathrm{b}}$ & $7.83^{\mathrm{a}}$ & 0.15 \\
\hline \multicolumn{7}{|c|}{ Individual volatile fatty acid (mol/100 $\mathbf{m o l})$} \\
\hline Acetic acid & $49.88^{\mathrm{ab}}$ & $50.63^{\mathrm{a}}$ & $46.32^{\mathrm{b}}$ & 1.87 & 49.24 & 47.32 & 1.53 \\
Propionic acid & 25.45 & 25.48 & 27.56 & 0.87 & 25.92 & 25.41 & 0.71 \\
Butyric acid & 22.76 & 21.38 & 24.34 & 4.71 & 21.55 & 25.27 & 3.85 \\
Iso-butyric acid & 1.13 & 1.07 & 1.05 & 0.24 & $1.63^{\mathrm{a}}$ & $0.53^{\mathrm{b}}$ & 0.20 \\
Iso-Valeric acid & 0.78 & 0.52 & 0.51 & 0.19 & 0.70 & 0.51 & 0.15 \\
\hline
\end{tabular}

Means within the same row having different superscripts are significantly different $(P<0.05)$.

As for nitrogen fractions in the rumen liquor of calves, Table (5) revealed that TN and TPN gave their highest significant $(P<0.05)$ values when animals were fed diet $(3)$ and both increased significantly $(\mathrm{P}<0.05)$ after $4 \mathrm{hrs}$ from feeding compared to their values before feeding. On the other hand, ruminal NPN and $\mathrm{NH}_{3}-\mathrm{N}$ concentrations were significantly lower $(\mathrm{P}<0.05)$ in calves consumed protected proteins (diets 2 and 3 ) compared to those received the untreated proteins (diet 1). All nitrogen fraction in rumen liquor of calves were significantly $(P<0.05)$ increased after 4 hrs post feeding compared to those recorded before feeding. Generally, the low values of both $\mathrm{NPN}$ and $\mathrm{NH}_{3}-\mathrm{N}$ and the increased values of TPN obtained in the present study could be reflections to the declined solubility and degradability of protein in the rumen as a result of $\mathrm{Zn}$ treatment, which would in turn positively increase the RUP.

Protozoa count (Table 5 and Figure 1$)$ significantly $(P<0.05)$ differed among the tested diets with the highest values in diets (3) reflecting the suitable $\mathrm{pH}$ values recorded with the same diet (Table 4). This could contribute to the enhanced digestibility coefficients of the same diet (Table 3 ). This effect for protozoa may not be because of $\mathrm{Zn}$ treatment as much as the rumen fermentation environment. In this concern, this explanation could be confirmed by the results obtained by Cecava et al. (1993) since they recorded 
that ruminal fermentation of $\mathrm{OM}$, ruminal NH3-N concentrations, and protoza populations were unaffected by dietary $\mathrm{Zn}$.

Table (5): Mean effect of feeding the experimental diets on rumen liquor nitrogen and protozoa count of Friesian cross-bred calves.

\begin{tabular}{|c|c|c|c|c|c|c|c|}
\hline \multirow{2}{*}{ Items } & \multicolumn{3}{|c|}{ Experimental diets } & \multirow[t]{2}{*}{ SEM } & \multicolumn{2}{|c|}{$\begin{array}{l}\text { Sampling } \\
\text { time (hr) }\end{array}$} & \multirow[t]{2}{*}{ SEM } \\
\hline & \begin{tabular}{|l|} 
Diet 1 \\
\end{tabular} & Diet 2 & Diet 3 & & 0 & 4 & \\
\hline Total nitrogen (TN, mg/100 ml RL) & $124.50^{6}$ & $129.33^{\mathrm{ab}}$ & $133.50^{\mathrm{a}}$ & 1.85 & $91.1^{\mathrm{b}}$ & $167.1^{\mathrm{a}}$ & 1.51 \\
\hline Non-protein nitrogen (NPN, mg/100 ml RL) & $54.33^{\mathrm{a}}$ & $39.83^{b}$ & $36.67^{c}$ & 0.76 & $31.1^{\mathrm{b}}$ & $56.1^{\mathrm{a}}$ & 0.62 \\
\hline $\mathrm{NH}_{3}-\mathrm{N}(\mathrm{mg} / 100 \mathrm{ml} \mathrm{RL})$ & $20.91^{\mathrm{a}}$ & $14.84^{b}$ & $14.77^{b}$ & 0.57 & $14.5^{\mathrm{b}}$ & $19.2^{\mathrm{a}}$ & 0.47 \\
\hline True-protein nitrogen (TPN, mg/100 ml RL) & $70.17^{c}$ & $89.50^{b}$ & $96.83^{\mathrm{a}}$ & 2.02 & $60.0^{\mathrm{b}}$ & $111.0^{\mathrm{a}}$ & 1.65 \\
\hline Protozoa Count $\times 10^{3} / \mathrm{ml}$ & $550^{c}$ & $695^{\mathrm{b}}$ & $848^{a}$ & 14 & $571^{b}$ & $824^{\mathrm{a}}$ & 12 \\
\hline
\end{tabular}

Means within the same row having different superscripts are significantly different $(P<0.05)$.

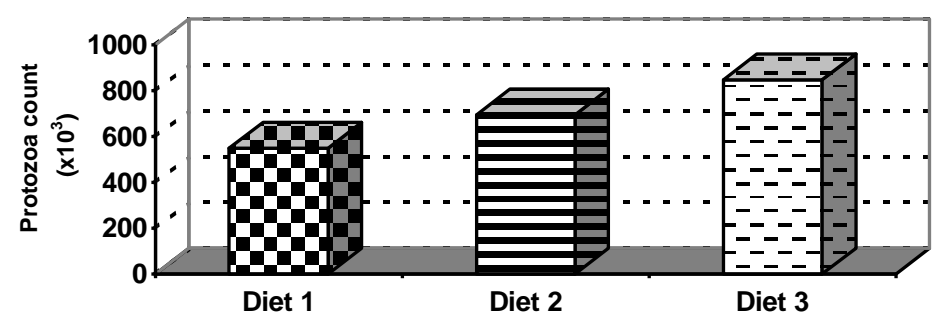

Figure (1): Protozoa count $\left(\times 10^{3}\right) / \mathrm{ml}$ of rumen liquor collected from the growing Friesian crossbred calves fed the experimental diets.

\section{Blood constituents:}

Concerning the effect of protected protein on some plasma metabolites (Table 6), lower $(\mathrm{P}<0.05)$ value of urea-N was found in plasma of calves received protected protein (diets 2 and 3 ) than those received unprotected protein (diet 1). The reduction in urea- $\mathrm{N}$ concentration for calves fed diet 3 and diet 2 were 3.46 and $3.29 \mathrm{mg} / 100 \mathrm{ml}$, respectively than that of the control. The obtained results in this study were close to the previous findings reported by El-Shabrawy (2006) who found that feeding goats on diet containing formaldehyde or heat treated SBM or soybean seeds (high RUP) reduced plasma urea- $\mathrm{N}$ by 2.88 and $2.22 \mathrm{mg} / 100 \mathrm{ml}$ plasma compared to those fed the diet contained untreated SBM (low RUP).

The reduction in blood urea- $\mathrm{N}$ concentration for calves given diets contained protected protein may be due to the decrease in rumen degradable protein, consequently decreased $\mathrm{NH}_{3}-\mathrm{N}$ concentrations in the rumen liquor (Table 5). Whereas, higher $(\mathrm{P}<0.05)$ values of total protein and its fractions (albumin and globulin) were recorded for calves given diets 2 and 3 than those given diet 1 . Moreover, sampling time as well as its interaction with tested diets did not show significant effect on all measured blood parameters, except the interaction which showed to significantly $(\mathrm{P}<0.05)$ affect urea-N levels. High levels of plasma protein reflect a good nutritional status of the animals (O'Kelly, 1973). The results obtained in this study were similar to the previous findings reported by El-Shabrawy et al. (2004) who found 
significantly higher levels of protein in plasma of animals fed protected protein. This may be due to higher RUP, which consequently increased amino acids supply in the small intestine.

Table (6): Mean values of blood constituents' concentrations of Friesian cross-bred calves fed the three experimental diets.

\begin{tabular}{|c|c|c|c|c|c|c|c|}
\hline \multirow{2}{*}{ Items } & \multicolumn{3}{|c|}{ Experimental diets } & \multirow[t]{2}{*}{ SEM } & \multicolumn{2}{|c|}{$\begin{array}{l}\text { Sampling } \\
\text { time (hr) }\end{array}$} & \multirow[t]{2}{*}{ SEM } \\
\hline & Diet 1 & Diet 2 & Diet 3 & & 0 & 4 & \\
\hline Urea-N (mg/100 ml) & $15.76^{\mathrm{a}}$ & $12.47^{b}$ & $12.30^{b}$ & 0.35 & 13.54 & 13.48 & 0.17 \\
\hline Total protein $(\mathrm{g} / 100 \mathrm{ml})$ & $6.68^{b}$ & $7.48^{\mathrm{a}}$ & $7.68^{\mathrm{a}}$ & 0.07 & 7.74 & 7.31 & 0.06 \\
\hline Albumin (A, g/100 ml) & $3.66^{\mathrm{C}}$ & $4.16^{\mathrm{b}}$ & $4.29^{\mathrm{a}}$ & 0.02 & 4.03 & 4.05 & 0.02 \\
\hline Globulin (G, g/100 ml) & $3.01^{b}$ & $3.32^{\mathrm{a}}$ & $3.39^{\mathrm{a}}$ & 0.07 & 3.21 & 3.26 & 0.07 \\
\hline A / G ratio & 1.22 & 1.26 & 1.27 & 0.03 & 1.26 & 1.24 & 0.03 \\
\hline $\mathrm{Zn}(\mathrm{mg} / \mathrm{dl})$ & 39.29 & 56.02 & 64.82 & 12.15 & 58.04 & 48.71 & 10.47 \\
\hline $\mathrm{Ca}(\mathrm{mg} / \mathrm{dl})$ & 6.29 & 6.54 & 5.90 & 1.26 & 5.29 & 7.20 & 1.05 \\
\hline 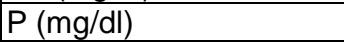 & 6.67 & .00 & 6.61 & 0.43 & 6.37 & 6.49 & 0.33 \\
\hline
\end{tabular}

Means within the same row having different superscripts are significantly different $(\mathrm{P}<0.05)$.

There were no significant differences among tested groups in their plasma $\mathrm{Zn}, \mathrm{Ca}$ and $\mathrm{P}$ concentrations due to feeding the experimental diets. These results are in agreement with those obtained by Nunnery et al. (2007) who stated that serum $\mathrm{Zn}$ concentration and specific ovalbumin IgG titers did not differ $(P>0.10)$ among 4 treatments on any sampling day. Puchala et al. (1999) found that plasma $\mathrm{Zn}$ concentrations were similar for animals fed diets contained $\mathrm{Zn}$-methionine, $\mathrm{Zn}$-oxide and the control group and generally all values were within the normal range for healthy goats.

\section{Growth performance:}

As shown in Table (7) and Figure (2), the ADG was higher $(P<0.05)$ for calves fed diet 3 followed by calves fed diet 2 then those fed diet 1 , being $1.272,1.178$ and $0.962 \mathrm{Kg} / \mathrm{h} /$ day, respectively.

Puchala et al. (1999) reported that yearling Angora goats fed diet containing zinc-methionine had higher ADG than the control ones. Habib et al. (2001) found that the growth performance of lambs was improved by the supplementation of RUP in diets.

Data in Table (7) also showed that intakes from DM, TDN and DCP increased for calves fed on diets contained protected protein by $\mathrm{Zn}$ than those fed diet contained untreated protein which was naturally a reflection of better body weight gains. These results are in agreement with those obtained by Can et al. (2004) who reported that male lambs fed rations containing ruminal un-degradable protein (RUP) increased DM intake.

The results of feed conversion ( $\mathrm{Kg} \mathrm{DM} / \mathrm{Kg}$ gain) showed that calves fed diets containing $\mathrm{Zn}$-treated protein (diet 3$)$ recorded the best $(P<0.05)$ value flowed by calves fed diets contained $\mathrm{Zn}$-treated protein and untreated protein with 50:50 ratio (diet 2) than those fed untreated protein (diet 1) which recorded the poorest value. The feed conversion (Kg DM / Kg gain) was improved by 11.28 or $11.19 \%$ for calves fed diet 3 or diet 2 , respectively than those received diet 1 . These results are in agreement with those obtained by Can et al. (2004) who stated that male lambs fed diets containing 5\% RUP 
increased feed conversion efficiency. Smartz et al. (1991) reported that increasing the RUP of the diet was beneficial in improving ADG and feed efficiency in young growing Holstein calves (wk 14 to 25) when they were fed ad libitum. Moreover, Ponnampalam et al. (2006) reported that fish meal (higher RUP) resulted in better growth rates and feed efficiency for lambs as compared to cannola meal and SBM (lower RDP).

Table (7): Live body weight gain, feed intake and feed conversion of Friesian cross-bred calves fed the experimental diets.

\begin{tabular}{|l|c|c|c|c|}
\hline \multirow{2}{*}{\multicolumn{1}{|c|}{ Items }} & \multicolumn{3}{c|}{ Experimental diets } & \multirow{2}{*}{ SEM } \\
\cline { 2 - 4 } & Diet 1 & Diet 2 & Diet 3 & \\
\hline Experimental period, day & 180 & 180 & 180 & - \\
\hline Calves No. & 6 & 6 & 6 & - \\
\hline Initial body weight (IBW), Kg & 96.0 & 97.0 & 93.0 & 3.1 \\
\hline Final body weight (FBW), Kg & $269.2^{\mathrm{b}}$ & $309.0^{\mathrm{a}}$ & $322.0^{\mathrm{b}}$ & 7.5 \\
\hline Total gain, Kg & $173.2^{\mathrm{C}}$ & $212.0^{\mathrm{b}}$ & $229.0^{\mathrm{a}}$ & 5.47 \\
\hline Average daily gain (ADG), Kg/h/d & $0.962^{\mathrm{C}}$ & $1.178^{\mathrm{D}}$ & $1.272^{\mathrm{a}}$ & 0.030 \\
\hline DM Intake, Kg/h/d & 6.07 & 6.60 & 7.12 & - \\
\hline TDN Intake, Kg/h/d & 3.914 & 4.452 & 4.911 & - \\
\hline DCP Intake, Kg/h/d & 0.603 & 0.621 & 0.766 & - \\
\hline Feed Conversion: & & & & \\
Kg DM / Kg gain & 6.309 & 5.603 & 5.597 & - \\
Kg TDN / Kg gain & 4.069 & 3.779 & 3.861 & - \\
Kg DCP / Kg gain & 0.627 & 0.586 & 0.602 & - \\
\hline
\end{tabular}

Means within the same row having different superscripts are significantly different $(P<0.05)$.

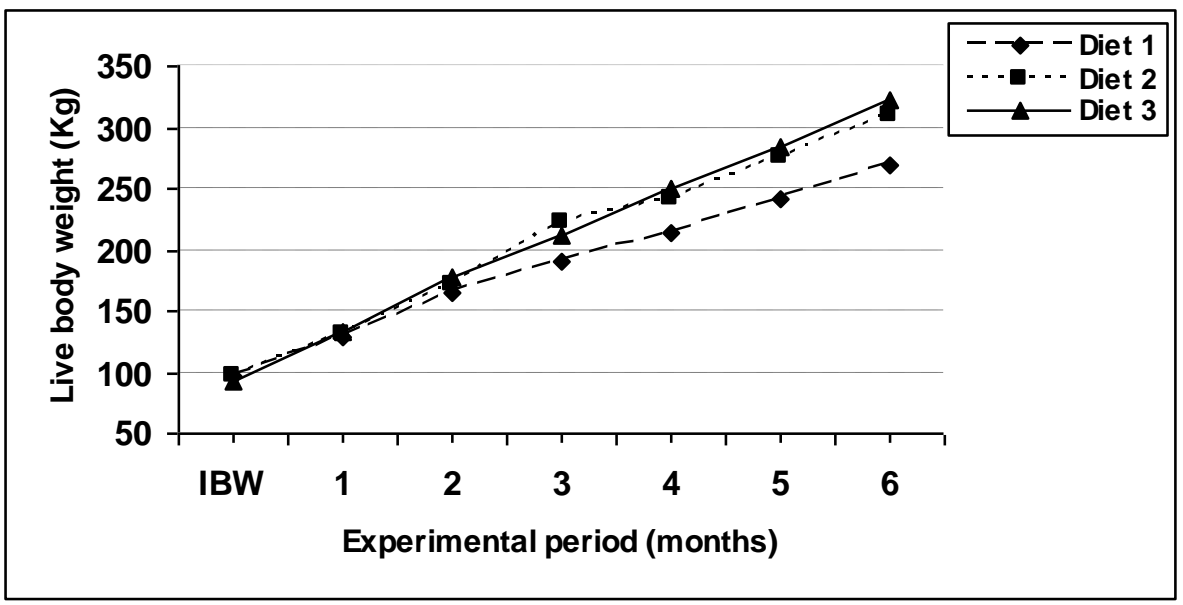

Figure (2): Live body weight changes of Friesian crossbred calves during the experimental period.

\section{Economical evaluation:}

Economical efficiency parameters listed in Table (8) showed improved values of efficiency with feeding calves on diets 2 and 3 compared to that recorded for feeding animals diet 1 . These results indicated that feed 
cost / Kg gain was lower for calves received diets 3 and 2 contained protected protein than those received diet contained the unprotected protein, being $4.15,4.39$ and 5.91 L.E., respectively. Consequently, the economic efficiency was improved for calves fed protected protein (diets 2 and 3) by $38.8 \%$ than those fed unprotected protein (diet 1$)$.

Table (8): Economical efficiency of the experimental diets used in growing cross-bred calves.

\begin{tabular}{|l|c|c|c|}
\hline \multirow{2}{*}{\multicolumn{1}{c|}{ Items }} & \multicolumn{3}{c|}{ Experimental diets } \\
\cline { 2 - 4 } & Diet 1 & Diet 2 & Diet 3 \\
\hline Daily feed Intake (Kg/h/d) as fed: & & & \\
WCS & 13.29 & 14.45 & 15.59 \\
SBM & 0.675 & 0.367 & - \\
Zn-SBM & - & 0.373 & 0.805 \\
UCSM & 1.348 & 0.733 & - \\
Zn-UCSM & - & 0.745 & 1.607 \\
\hline Daily feeding costs (L.E) & 5.47 & 6.09 & 6.72 \\
\hline Daily weight gain, Kg/h/d & 0.962 & 1.178 & 1.272 \\
\hline Price of daily gain (L.E) & 5.69 & 5.17 & 5.28 \\
\hline Feed costs/Kg gain (L.E) & 5.91 & 4.39 & 4.15 \\
\hline Economic efficiency & 3.04 & 4.10 & 4.34 \\
\hline
\end{tabular}

The price list of one ton WCS, SBM, Zn-SBM, UCSM and Zn-UCSM were 150, 2750, 2850 1200 and 1300 L.E., respectively and price of one $\mathrm{Kg}$ for live body weight was $18 \mathrm{L.E}$. (Based on year 2008 prices).

On the light of the above mentioned results the use of zinc sulphate to protect half or all of SMN and UCSM dietary protein from degradation in the rumen of Friesian crossbred calves was of beneficial effect on their growth performance indicating better utilization of the treated diets compared to that untreated ones.

\section{REFERENCES}

Abou El-Naga, M.A. (1967). Some metabolic studies on rumen microorganisms. M. Sc. Thesis, Faculty of Agriculture, Alexandria University, Egypt.

Abou-Raya, A.K. (1967). Animal Nutrition. Arabic Text Book, Dar El-Maaref, Cairo, Egypt.

A.O.A.C. (1990). Official Methods of Analysis. Association of Official Analytical Chemists, $15^{\text {th }}$ Ed., Washington D.C., USA.

Britton, R.A. and T.J. Klopfenstein (1986). Zinc treated soybean meal: A method to increase bypass. Nebraska 1986 Beef Cattle Rep. MP-50. P 45 Lincoln.

Can, A.; N.D. Denek and S. Tufenk (2004). Effect of escape protein level on finishing performance of Awassi lambs. Small Rumin. Res.,55:215-219.

Cecava, M.J.; D.L. Hancock and J.E. Parker (1993). Effects of zinc-treated soybean meal on ruminal fermentation and intestinal amino acid flows in steers fed corn silage-based diets. J. Anim. Sci. (71):3423-3431.

Conway, E.J. and E. O'Mally (1957). Micro diffusion methods. Ammonia and urea using buffered absorbents. Biochem. J., 36:655. 
Duncan, D.B. (1955). Multiple range and multiple F-test. Biometrics, 11:1-42.

El-Shabrawy, H.M.,(2000). Effect of protected proteins on the milk yield. Influence of protecting cotton seed and soybean proteins by either heat or formaldehyde treatments on some metabolic and performance traits of cows. Ph.D. Thesis, Fac. of Agric., Mansoura Univ., Egypt.

El-Shabrawy, H.M. (2006). Performance of goats fed protected protein during gestation and lactation. Egypt. J. of Sheep, Goats and Desert Animals Sciences, Vol. 1 (1): 213-232. Supl. Issue for the $1^{\text {st }}$ Conference of Enhancement of Small Ruminants Production, 7-9 Feb. 2006 (Cairo).

El- Shabrawy, H.M. and H.A. El-Fadaly (2006). Effect of feeding regime and formaldehyde treatment of diets for crossbred Friesian cows on their milk productivity and microbiology. Egyptian J .Anim. Prod.,43(1):2539.

El-Shabrawy, H.M.; A.Z. Mehrez,. and E.I. Shehata (2004). Evaluation of alfalfa hay and silage in complete diets for lactating goats. The $12^{\text {th }}$ Conf. of the Egyptian Society of Animal Production, Mansoura, $30^{\text {th }}$ Nov. $2^{\text {nd }}$ Dec., Proc. of the Egypt. J. Anim. Prod., 41 (Suppl. Issue): 181-194.

Erwin, E.S.; G.T. Marco and E.M. Emery (1961). Volatile fatty acid analysis of blood and rumen fluid by gas chromatography. J. Dairy Sci., 44: 1768.

Froetschel, M.A.; A.C. Martin; H.E. Amos and J.J. Evans (1990). Effects of zinc sulfate concentration and feeding frequency on ruminal protozoal numbers, fermentation patterns and amino acid passage in steers. J. Anim. Sci., 68: 2874.

Habib, G.; M.M. Siddiqui, F.H. Mian, J. Jabar and F. Khan (2001). Effect of protein supplement of varying degradability on growth rate, wool yield and wool quality in grazing lambs. Small Rumin. Res., 41: 247-256

Haddad, S.G.; K.Z. Mahmoud and H.A. Talha (2005). Effect of varying levels of dietary undergradable protein on nutrient intake, digestibility and growth performance of Awassi lambs fed on high wheat straw diets. Small Rumin Res., 58: 231-236

Haurowitz, F. (1950). Chemistry and Biology of Proteins. Academic Press, New York.

Karr, K.J.; K.A. Dawson and G.E. Mitchell, Jr. (1991a). Inhibitory effects of zinc on the growth and proteolytic activity selected strains of ruminal bacteria. P. 27. Beef Cattle Res. Rep. No. 337, Univ. of Kentucky, Lexington.

Karr, K.J.; K.A. Dawson and G.E. Mitchell, Jr. (1991b). Ruminal flow of nitrogen and amino acids in sheep fed $\mathrm{Zn}$-treated soybean meal. $21^{\text {st }}$ Biennial Conf. on rumen function, No. 35. (Abstr.).

Karr, K.J.; K.A. Dawson and G.E. Mitchell, Jr. (1991c). Zinc protected soybean meal as a source of protein for growing calves. P. 21. Beef Cattle Res. Rep. No. 337, Univ. of Kentucky, Lexington.

Kincaid, R.L.; W.J. Miller; P.R. Fowler; R.P. Gentry; D.L. Hamption and M.W. Neathery (1976). Effect of high dietary zinc upon zinc metabolism and intracellular distribution in cows and calves. J. Dairy Sci.,59:1580-1584.

MAO (1997). Ministry of Agriculture and Land Reclamation, Agric. Res. Center, Animal Prod. Res Inst., Dokki, Egypt. Animal Nutrition " Scientifically and Practically"- In Arabic. 
Miller, W.J.; C.M. Clifton; P.R. Fowler and H.F. Perkins (1965). Influence of high levels of dietary zinc on zinc in milk performance and biochemistry of lactating cows. J. Dairy Sci., 48:450.

National Research Council, NRC (1989). Nutrient Requirements of Dairy Cattle. $9^{\text {th }}$ Rev. ed., Natl. Acad. Sci., Washington, DC.

Nunnery, G.A.; J.T. Vasconcelos; C.H. Parsons; G.B. Salyer; P.J. Defoor; F.R. Valdez and M.L. Galyean (2007). Effects of source of supplemental zinc on performance and humoral immunity in beef heifers. J. Anim. Sci., 85: 2304-2313.

O'kelly, J.C. (1973). Seasonal variation in the plasma lipids of genetically different types of cattle steers on different diets. Comp. Biochem. Physical., 44: 303.

Patton, C.J. and S.R. Crouch (1977). Anal. Chem., 49:464-469. (Cited from Diamond Company, France).

Peters, T. (1968). Determination of serum total protein. Clin. Chan., 14:1147.

Pires, A.V.; M.L. Eastridge.; J.L. Firkins and Y.C. Lin (1997). Effect of heat treatment and physical processing of cottonseed on nutrient digestibility and production performance by lactating cows. J. Dairy Sci., 80:1685.

Ponnampalam, E.N.; A.R. Egan, A.J. Sinclair and B.J. Leury (2006). Feed intake, growth, plasma glucose and urea nitrogen concentration and carcass traits of lams fed iso-energetic amounts of canola meal, soyabean meal and fish meal with forage based diet, Small Rumin. Res., 56: 245-252

Puchala, R.; T. Sahlu and J.J. Davis (1999). Effects of zinc-methionine on performance of Angora goats. Small Ruminant Research, 33: 1-8.

SAS (1996). Statistical Analysis System. Users Guide Statistics. SAS Institute, Cary, North Carolina.

Smartz, L.A.; A.J. Heinrichs; G.A. Varga and L.D. Muller (1991). Effects of varying dietary undegradable protein on dry matter intake, growth and carcass composition of Holstein calves. J. Dairy Sci., 74: 3884-3890.

Soto-Navarro, S.A.; R. Puchala, T. Sahlu and A.L. Goetsch (2006). Effect of dietary rations of fish and blood meals on sites of digestion, small intestinal amino acids disappearence and growth performance of meat goat wethers. Small Rum. Res., 64: 255-267

Van Keulen, J. and B.R. Young (1977). Evaluation of acid-insoluble ash as a natural marker in ruminant digestibility studies. J. Anim. Sci., 44:282.

Warner, A.C.I. (1964). Production of volatile fatty acids in the rumen. Methods of measurements. Nutr. Abst. Rev., 34:339.

Webster, D. (1974). Determination of serum albumin. Clin. Chem. Acta, 53:109. (Cited from Bicon Company, Germany).

Zimmerman, C.A.; A.H. Rakes; T.E. Daniel and B.A. Hopkins (1992). Effect of total and rumen undegradable protein on the performance of cows fed low fiber diets. J. Dairy Sci., 75: 1954. 
El-Shabrawy, H.M. et al.

تأثير البروتين المحمي على الآداء الإنتاجي لعجول خليط الفريزيسان المغذاة على سيلاج الأذرة كعليقة أسناسية

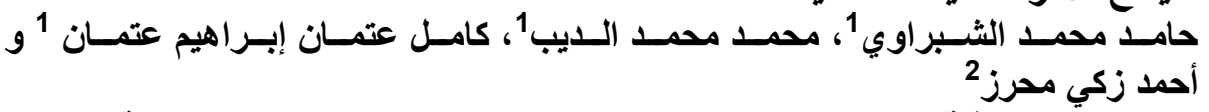
1- قسم بحوث تغذية الحيوانـ معهز بحوث الإتتاج الحيواني ـ مركز البحوث الزراعية ـ وزارة

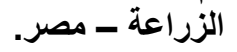
2- قسم إنتاج الحيوان ـ كلية الزراعة - جامعة المنصورة.

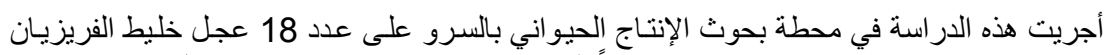

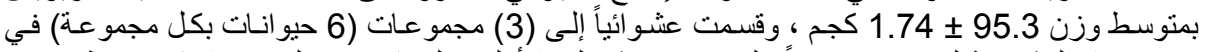

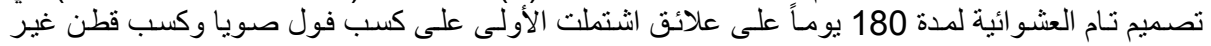

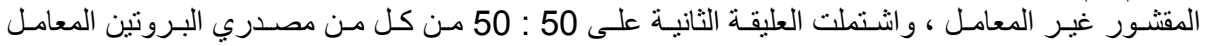

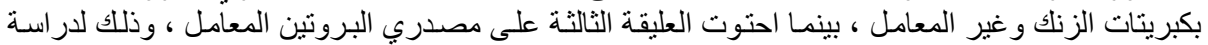

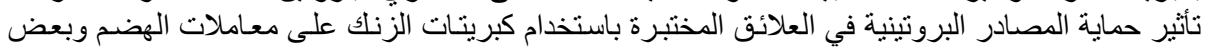

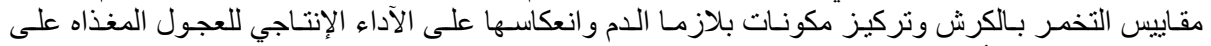
سيلاج الذره كعليقه أساسيه

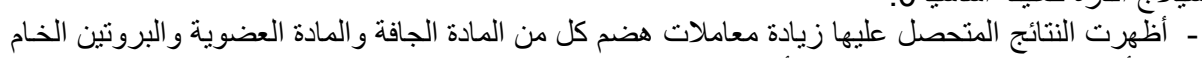

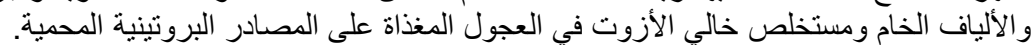

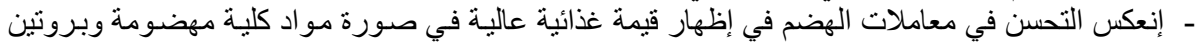

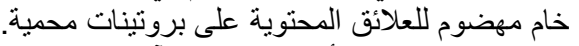

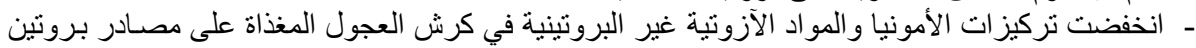

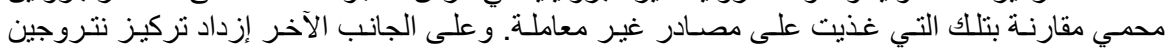

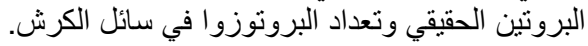

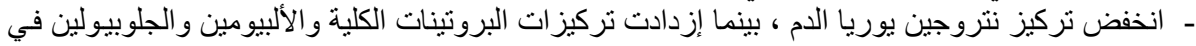

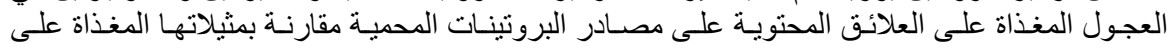
مصادر غير المحمية. - إزداد معدل النمو اليومية بمقار 1.272 و 1.178 كجم/رأس/يوم في المجموعة الثالثة و الثانية بالمقارنة

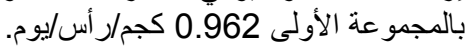

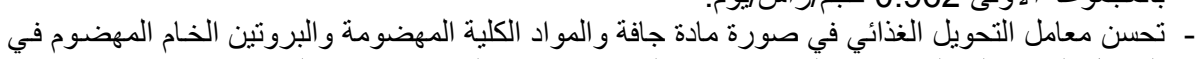

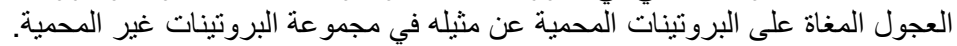

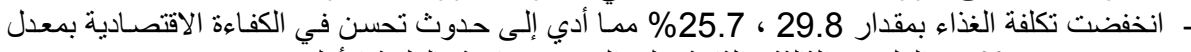

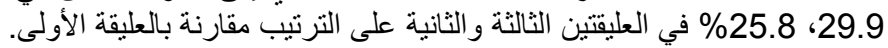

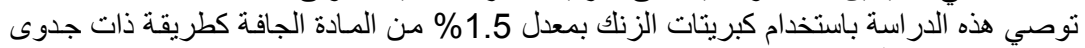

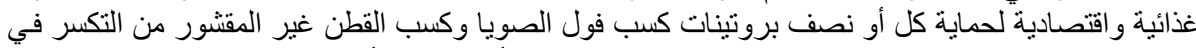
الكرش في علائق العجول خليط الفريزيان المغذاة على سيلاج الأذرة كعليقة أساسية.

كلية الزراعة - جامعة المنصورة أكاديمية البحث العلمي

$$
\text { قام بتحكيم البحث }
$$

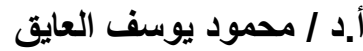

أ. أد / محسن محمود شكري العايق 